\title{
Neer Type II Distal End Clavicular Fracture: Outcome with Clavicular Hook Plate Fixation
}

Sagar Panthi', Rishiswor Shrestha', Sabal Krishna Gaihre², Angelica Karki³, Suyachha Chettri ${ }^{4}$

\section{Author Info:}

1Department of Orthopaedics and Traumatology, Rapti Academy of Health Sciences, Ghorahi, Dang, Nepal

${ }^{2}$ Department of Orthopaedics and Traumatology, Rapti Provincal Hospital, Tulsipur, Dang, Nepal

${ }^{3}$ Department of Orthodontics and Dentofacial Orthopaedics, Rapti Academy of Health Sciences, Ghorahi, Dang, Nepal

${ }^{4}$ Department of Cardiothoracic and Vascular Surgery, Shahid Gangalal National heart care Center, Bansbari, Kathmandu, Nepal

\section{Corresponding Author:}

Dr. Sagar Panthi, Email/Contact: drsagarmsortho@gmail.com +977-9857036678

\section{ABSTRACT}

Background: Distal end clavicular fractures are rare type of injuries seen in adult population. These fractures are unstable because of various deforming forces. Clavicular hook plate aligns the clavicle along with ligaments. The aim of this study is to observe the outcome of displaced distal end clavicular fracture managed with hook plate fixation.

Methods: Twenty five patients with displaced distal end clavicular fractures (Neer type II) were evaluated retrospectively from November 2018 to August 2020. Functional outcome were assessed via Constant and Murley score at one year final follow-up.

Results: Sixty percent of patient had excellent outcome, $32 \%$ of patient had good outcome and $8 \%$ of patient had fair outcome at final follow-up. Mean Constant and Murley score was 86 . Four patients developed subacromial osteolysis which resolved at final follow-up. One patient had extra-articular ossification whereas none of the patient developed non-union and AC joint arthrosis.

Conclusion: Clavicular hook plate provides stable fixation of distal end clavicular fracture with few complications and is cost-effective.

Keywords: Clavicular Hook Plate; Complications; Distal End Clavicular Fractures; Subacromial Osteolysis

Article Info
Received: 28 September 2020; Accepted: 15 October 2020; Published Online: 16 October 2020
How to cite this article in Vancouver Style?
$\begin{aligned} & \text { Panthi S, Shrestha R, Gaihre SK, Karki Angelica, Chettri S. Neer Type II Distal End Clavicular Fracture: } \\ & \text { Outcome with Clavicular Hook Plate Fixation. Europasian J Med Sci.2020;2(2):78-83. https://doi. } \\ & \text { org/10.46405/ejms.v2i2.195 }\end{aligned}$
$\begin{aligned} & \text { Conflict of Interest: None Declared; } \\ & \text { The Europasian Journal of Medical Sciences (EJMS) remains neutral with regard to jurisdictional claims in published articles and } \\ & \text { institutional affiliations. }\end{aligned}$


15.24 weeks which is comparable to several authors who managed distal end clavicular fractures with hook plate and concluded good results in terms of fracture union and shoulder function. ${ }^{23,27-31}$

Subacromial impingement syndrome, subacromial bursitis and subacromial osteolysis are the common complications of hook plate which is due to mismatch between configuration of plate and anatomy of clavicle. This type of complications occurs during overhead abduction during rehabilitation period. ${ }^{32}$ Four patients in our study developed subacromial osteolysis which resolved at final follow-up. This is a self-limiting complication as it subsides gradually after implant removal. In the study done by Lee et al $17 \%$ of the patient develops subacromial osteolysis. ${ }^{33}$ Even these short term complications have the chances of supraspinatus rupture and acromion fracture but these complications were not reported with hook plate fixation in any literature. ${ }^{30}$

In the study done by Kapil Mani KC et al they used a pre countered clavicular locking plate with broad lateral end in 46 patients. The mean time of fracture union was 15.28 weeks and mean Constant and Murley score was 92.56 which was comparable to our study. ${ }^{34}$ Various authors discouraged this implant as there is the high chance of developing AC joint arthrosis and extra-articular ossifications. This occurs due to proximity of hook of the plate to acromioclavicular joint. ${ }^{17,35}$ In our study, one patient develops extra-articular ossification but the shoulder range of motion was normal at the final follow-up and none of the patients developed AC joint arthrosis.

We have calculated the cost of pre countered clavicular locking plate with broad lateral ends that costs (28000 rupees or 240 US dollars) and clavicular hook plate (14,000 rupees or 119 US dollar). Since our country being low socioeconomic status, using the clavicular hook plate becomes beneficial as it is relatively cheaper than other locking plate system thereby preventing economic burden to the patient and their relatives.

\section{CONCLUSION}

Clavicular hook plate is better choice for management of distal end clavicular fractures. This technique can provide faster rehabilitation and rapid recovery. It has less complications and it is cost-effective.

\section{REFERENCES}

1. Heckman JD, McKee M, McQueen MM, Ricci W, Tornetta III P. Rockwood and Green's fractures in adults. Lippincott Williams \& Wilkins; 2014 Sep 4. [Google Scholar]

2. Charles S, Neer I (1963) Fracture of the distal clavicle with detachment of the coracoclavicular ligaments in adults. Journal of Trauma and Acute Care Surgery 3(2): 99-110. https://doi.org/10.1097/00005373196303000-00001 [PubMed] [Google Scholar]

3. Meda PV, Machani B, Sinopidis C, Braithwaite I, Brownson P, et al. (2006) Clavicular hook plate for lateral end fractures: a prospective study. Injur 37(3): 277-283. $\quad$ https://doi.org/10.1016/j. injury.2005.10.017 [PubMed] [Google Scholar]

4. Vaishya R, Vijay V, Khanna V. Outcome of distal end clavicle fractures treated with locking plates. Chin J Traumatol. 2017; 20(1): 45-8. https://doi. org/10.1016/j.cjtee.2016.05.003 [PubMed] [Google Scholar] [PMC] [Full Text]

5. Samy $M$, Khanfour A. Extra-articular fixation of displaced fracture lateral end clavicle. Eur J Orthop Surg Traumatol. 2011; 21(8): 557-61. https://doi. org/10.1007/s00590-011-0771-4 [Google Scholar]

6. Kalamaras M, Cutbush K, Robinson M. A method for internal fixation of unstable distal clavicle fractures: early observations using a new technique. J Shoulder Elbow Surg. 2008; 17(1): 60-2. https://doi. org/10.1016/j.jse.2007.04.012 [PubMed] [Google Scholar]

7. Rokito AS, Zuckerman JD, Shaari JM, Eisenberg DP, Cuomo F, Gallaher MA. A comparison of nonoperative and operative treatment of type II distal clavicle fractures. Bull Hosp Jt Dis. 2002-2003; 61(1-2): 32-39. [PubMed] [Full Text] [Google Scholar]

8. Robinson $C M$, Akhtar MA, Jenkins PJ, Sharpe $T$, Ray A, Olabi B. Open reduction and endobutton fixation of displaced fractures of the lateral end of the clavicle in younger patients. J Bone Joint Surg Br. 2010; 92(6): 811-6. https://doi.org/10.1302/0301620X.92B6.23558 [PubMed] [Google Scholar]

9. Sambandam B, Gupta R, Kumar S, Maini L. Fracture of distal end clavicle: A review. J Clin Orthop Trauma. 2014; 5(2): 65-73. https://doi.org/10.1016/j. jcot.2014.05.007 [PubMed] [PMC] [Full Text] [Google Scholar]

10. Jupiter JB, Leffert RD. Non-union of the clavicle. Associated complications and surgical management. J Bone Joint Surg Am. 1987; 69(5): 753-60. [PubMed] [Google Scholar]

11. Lee SK, Lee JW, Song DG, Choy WS. Precontoured locking plate fixation for displaced lateral clavicle fractures. Orthopedics. 2013; 36(6): 801-7. https:// doi.org/10.3928/01477447-20130523-28 [PubMed] 


\section{INTRODUCTION}

Clavicular fractures are common injuries in young adults. It accounts about $2.6 \%$ of all injuries. ${ }^{1}$ Midshaft clavicular fracture is the commonest type followed by distal end clavicular fracture. ${ }^{2,3}$ Distal end clavicular fractures accounts for 12 to $15 \%$ of all clavicular fractures. ${ }^{4}$ Non-union are more common in distal end clavicular fractures. Non-union occurs in 22 to $44 \%$ of population. This occurs as the weight of the arm distracts the distal part and counter pulls the trapezius muscle on proximal part. ${ }^{5-7}$ Treatment of non-union of distal end clavicular fractures are very challenging for good orthopaedic surgeon. ${ }^{8,9}$ It has the complications like loss of strength and painful shoulder movement. ${ }^{10}$

There are various methods of treatment for acute distal end clavicular fractures to prevent complications. ${ }^{11}$ It includes K-wire fixation, Tension band wiring, Bosworth technique, various angled locking compression plate and clavicular hook plate fixation. ${ }^{12-15}$ Some author prefers clavicular hook plate as it provide stable fixation of small fragments. ${ }^{16}$ These plate fixation techniques have higher union with less complication rates. ${ }^{17}$ The aim of this study is to observe the outcome of displaced distal end clavicular fractures managed with open reduction and internal fixation with clavicular hook plate.

\section{MATERIALS AND METHODS}

This is a retrospective study done in Rapti Academy of Health Science, Ghorahi, Dang in between November 2018 to August 2020. 28 patients with displaced distal end clavicular fractures (Neer Type II) were included in our study. Sample size was taken by convenient sample size. Non-displaced fracture, pathological fracture, compound fracture and patient who lost follow-up for implant removal were excluded from study. Permission from institutional review committee was obtained. All fractures were managed with open reduction and internal fixation with clavicular hook plate. The diagnosis and displacement of distal end clavicular fracture was confirmed by AP-radiographs of affected shoulder.

All surgeries were performed under interscalene block with anterior cervical plexus block. All patients were placed in beach chair position with turning the head on opposite side. The upper extremity over the involved side was prepared and drapped free for mobilization. Pre-operatively, $1 \mathrm{gm}$ of intravenous ceftriaxone was administered. A transverse incision was placed over the fracture just medial to AC joint. The fracture site was exposed by mobilizing trapezius muscle posteriorly and deltoid muscle anteriorly. Comminuted fragments were temporarily fixed with $\mathrm{K}$-wires. Torn ligaments were not repaired. The soft tissue was dissected from posterior aspect of AC joint to insert the hook of the plate. The plate is secured with $3.5 \mathrm{~mm}$ cortical screws and $4.0 \mathrm{~mm}$ cancellous screws. Wound was closed in layers and post-operatively the limb was supported with arm pouch sling. Pendulum exercises were started in $4^{\text {th }}$ post-operative day. Suture removal was done two weeks post-surgery. Implant removal was done 6 months post-surgery. At one year follow-up of fracture fixation surgery, final outcome was evaluated using Constant and Murley score. ${ }^{18}$

\section{RESULTS}

Out of 28 patients, 3 patients were lost for the follow-up for implant removal and were excluded from study. The mean age of patient was 33.68 years (ranging from 21 to 54 years). Mean interval between initial injury and surgery was 2.64 days (ranging from 1 to 7 days). Mean time of implant removal was 7.72 months (ranging from 6 to 11 months). Mean time of fracture union was 15.24 weeks (ranging from 13 to 19 weeks). Mean Constant and Murley score was 86 (ranging from 63 to 97). 1 patient had ipsilateral distal radius fracture that was managed with open reduction and internal fixation with volar locking plate in same setting. 1 patient had superficial wound infection that resolved with oral antibiotics. 4 patient developed subacromial osteolysis but it resolved at final follow-up. 1 patient developed extra-articular ossification. None of the patient had non-union and $\mathrm{AC}$ joint arthrosis. The outcome was graded excellent in 15 (60\%) patients, good in 8 (32\%) patients and fair in 2 (8\%) patients (Table 2) Basis of selection of Excellent, Good, Fair and Poor is according to Constant and Murley score.

Table 1: Characteristics of patients $(n=25)$

\begin{tabular}{|l|l|}
\hline Parameters & No. of cases (Percentage \%) \\
\hline Gender & \\
\hline Male & $12(48 \%)$ \\
\hline Female & $13(52 \%)$ \\
\hline Involved side & \\
\hline Right & $15(60 \%)$ \\
\hline Left & $10(40 \%)$ \\
\hline
\end{tabular}




\begin{tabular}{|c|c|c|}
\hline Outcome & No. of patients & Percentage (\%) \\
\hline Excellent & 15 & 60 \\
\hline Good & 8 & 32 \\
\hline Fair & 2 & 8 \\
\hline Poor & 0 & 0 \\
\hline
\end{tabular}

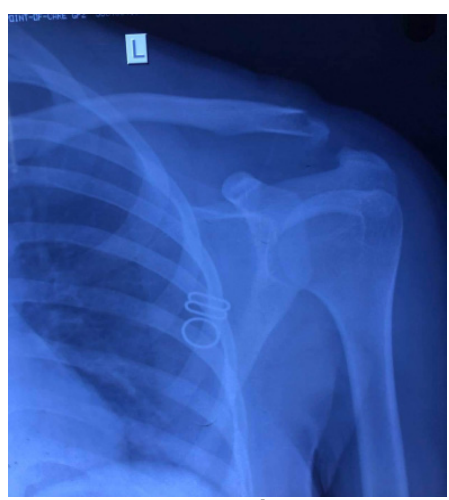

A

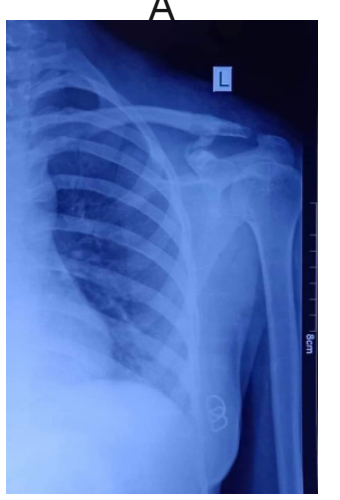

D
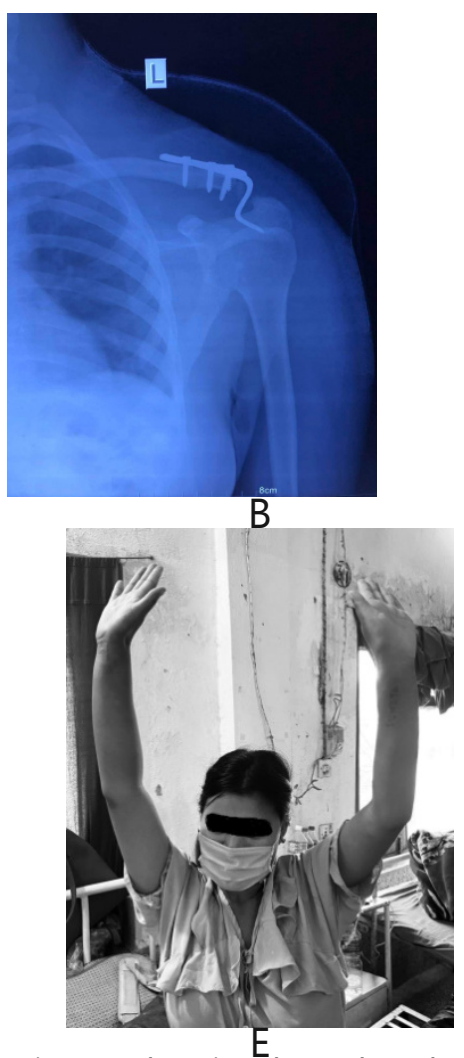

methods by various authors. In the study done by Rokito et al they concluded higher rate of non-union in those patients who were treated conservatively. ${ }^{7}$

Neer was the first author to manage distal end clavicular fractures by $\mathrm{K}$-wire fixation. ${ }^{21} \mathrm{~K}$-wire fixation have high complication rate like pin migration and superficial pin tract infection. ${ }^{22,15}$ In the study done by Lee et al, they compared the tension band wiring with hook plate fixation and

Figure 1: Radiographic and Clinical picture showing lateral end clavicular fracture (A) Pre-operative (B) Post-operative (C) At the time of implant removal (Extra-articular ossification) (D) After implant removal (Extra-articular ossification) (E) Clinical picture showing good overhead abduction at time of implant removal.

\section{DISCUSSION}

Mid-shaft clavicular fractures are one of the most common orthopaedic injuries. Distal end clavicular fractures are rare type of injuries seen in adult population. To gain stable fixation and early mobilization, clavicular hook plate is used to reduce small distal fragments in distal end clavicular fractures. ${ }^{19}$

Neer describe distal end clavicular fractures are unstable fractures that have higher rate of nonunion. Thus, operative treatment is mandatory in distal end clavicular fractures., ${ }^{7,21}$ Previously distal end clavicular fracture was treated by conservative they found early return to daily activities can be achieved by hook plate fixation. In their study they had $30 \%$ complications in tension band wiring fixation group. ${ }^{23}$

Clavicular fracture and coracoid fracture are well observed complications which is seen in

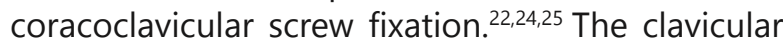
hook plate helps for reduction of distal end clavicle, that aligns the clavicle along with ligaments and it decreases the movement at fracture site. Rotational movement of clavicle is not interfered by hook plate fixation. ${ }^{26}$ The mean Constant and Murley score was 86 and mean time of fracture union was 


\section{[Google Scholar]}

12. Shin SJ, Roh KJ, Kim JO, Sohn HS. Treatment of unstable distal clavicle fractures using two suture anchors and suture tension bands. Injury. 2009; 40 (12): 1308-12. $\quad$ https://doi.org/10.1016/j. injury.2009.03.013 [PubMed] [Google Scholar]

13. Bezer M, Aydin N, Guven O. The treatment of distal clavicle fractures with coracoclavicular ligament disruption: a report of 10 cases. J Orthop Trauma. 2005; 19(8): 524-8. https://doi.org/10.1097/01. bot.0000164593.04348.e5 [PubMed] [Google Scholar] [Full Text]

14. Macheras G, Kateros KT, Savvidou OD, Sofianos J, Fawzy EA, Papagelopoulos PJ. Coracoclavicular screw fixation for unstable distal clavicle fractures. Orthopedics. 2005; 28(7): 693-6. [PubMed] [Google Scholar]

15. Flinkkila $T$, Ristiniemi J, Lakovaara $M$, Hyvonen $P$, Leppilahti J. Hook-plate fixation of unstable lateral clavicle fractures: a report on 63 patients. Acta Orthop. 2006; 77(4): 644-9. https://doi. org/10.1080/17453670610012737 [PubMed] [Full Text] [Google Scholar]

16. Kashii M, Inui $H$, Yamamoto K. Surgical treatment of distal clavicle fractures using the clavicular hook plate. Clin Orthop Relat Res. 2006; 447: 158-64. https://doi. org/10.1097/01.blo.0000203469.66055.6a [PubMed] [Full Text] [Google Scholar]

17. Kaipel M, Majewski M, Regazzoni P: DoublePlate Fixation in Lateral Clavicle Fractures-A New Strategy. J Trauma 2010. https://doi.org/10.1097/ TA.0b013e3181bedf28 [PubMed] [Full Text] [Google Scholar]

18. Constant $\mathrm{CR}$, Murley $\mathrm{AH}$. A clinical method of functional assessment of the shoulder. Clin Orthop Relat Res. 1987;214:160-4. [PubMed] [Google Scholar]

19. Yoo JH, Chang JD, Seo YJ, Shin JH. Stable fixation of distal clavicle fracture with comminuted superior cortex using oblique Tplate and cerclage wiring Injury. 2009; 40(4): 455-7. https://doi.org/10.1016/j. injury.2008.05.028 [PubMed] [Full Text] [Google Scholar]

20. Neer CS: Fractures of the distal third of the clavicle. Clin Orthop Relat Res 1968, 58:43-50. [PubMed] [Google Scholar]

21. Neer CS: Fracture of the distal clavicle with detachment of the coracoclavicular ligaments in adults. J Trauma 1963, 3:99-110. [PubMed] [Google Scholar]

22. Kona J, Bosse MJ, Staeheli JW, Rosseau RL: Type II distal clavicle fractures: a retrospective review of surgical treatment. J Orthop Trauma 1990, 4:115120. https://doi.org/10.1097/00005131-19900402000002 [PubMed] [Google Scholar]
23. Lee YS, Lau MJ, Tseng YC, Chen WC, Kao HY, Wei JD: Comparison of the efficacy of hook plate versus tension band wire in the treatment of unstable fractures of the distal clavicle. Int Orthop 2009, 33:1401-1405. https://doi.org/10.1007/s00264-0080696-7 [PubMed] [PMC] [Full Text] [Google Scholar]

24. Moneim MS, Balduini FC: Coracoid fracture as a complication of surgical treatment by coracoclavicular tape fixation. A case report. Clin Orthop Relat Res 1982, 133-135. [PubMed] [Google Scholar]

25. Eberle C, Fodor P, Metzger U: [Hook plate (so-called Balser plate) or tension banding with the Bosworth screw in complete acromioclavicular dislocation and clavicular fracture]. Z Unfallchir Versicherungsmed 1992, 85:134-139. [PubMed] [Google Scholar]

26. Kiefer $H$, Claes L, Burri C, Holzwarth J: The stabilizing effect of various implants on the torn acromioclavicular joint. A biomechanical study. Arch Orthop Trauma Surg 1986, 106:42-46. https:// doi.org/10.1007/BF00435651 [PubMed] [Google Scholar]

27. Tambe AD, Motkur P, Qamar A, Drew S, Turner SM: Fractures of the distal third of the clavicle treated by hook plating. Int Orthop 2006, 30:7-10. https://doi. org/10.1007/s00264-005-0019-1 [PubMed] [PMC] [Full Text] [Google Scholar]

28. Bhangal KK, Evans SC, Gibbons E: Treatment of Displaced Lateral Clavicle Fractures with the AO Hook Plate. European Journal of Trauma 2006, 5:468-470. https://doi.org/10.1007/s00068-0066012-6 [Google Scholar]

29. Haidar SG, Krishnan KM, Deshmukh SC: Hook plate fixation for type II fractures of the lateral end of the clavicle. J Shoulder Elbow Surg 2006, 15:419-423. https://doi.org/10.1016/j.jse.2005.11.012 [PubMed] [Full Text] [Google Scholar]

30. Muramatsu K, Shigetomi M, Matsunaga T, Murata $Y$, Taguchi T: Use of the AO hook-plate for treatment of unstable fractures of the distal clavicle. Arch Orthop Trauma Surg 2007, 127:191-194. https://doi. org/10.1007/s00402-006-0284-5 [PubMed] [Google Scholar]

31. Renger RJ, Roukema GR, Reurings JC, Raams PM, Font J, Verleisdonk EJ: The clavicle hook plate for Neer type II lateral clavicle fractures. J Orthop Trauma 2009, 23:570-574. https://doi.org/10.1097/ BOT.0b013e318193d878 [PubMed] [Google Scholar]

32. Davut Tiren, Alexander JM van Bemmel, Dingeman J Swank, Frits M van der Linden: Hook plate fixation of acute displaced lateral clavicle fractures: midterm results and a brief literature overview. Journal of Orthopaedic Surgery and Research 2012, 7:2-8. https://doi.org/10.1186/1749-799X-7-2 [Google Scholar] 
33. Lee KW, Lee SK, Kim KJ, Kim YI, Kwon WC, Choy WS: Arthroscopic-assisted Locking Compression Plate clavicular hook fixation for unstable fractures of the lateral end of the clavicle: a prospective study. Int Orthop 2009. https://doi.org/10.1007/s00264-0090925-8 [PubMed] [PMC] [Full Text] [Google Scholar]

34. KC Kapil-Mani, Acharya P, Arun S: Precontoured Clavicular Locking Plate with Broad Lateral End: A Newly Designed Plate for Lateral Third Clavicle Fractures. Malaysian Orthopaedic Journal 2018;12(1): 15-21. https://doi.org/10.5704/MOJ.1803.003 [PubMed] [PMC] [Google Scholar]

35. Jackson WF, Bayne G, Gregg-Smith SJ: Fractures of the lateral third of the clavicle: an anatomic approach to treatment. J Trauma 2006, 61:222-225. https://doi. org/10.1097/01.ta.0000196804.23024.a3 [PubMed] [Full Text] [Google Scholar] 